\title{
Perspectives on Policy/Practice (Dis)Connection-Special Educators Turned Teacher Educators’ Points of View
}

\author{
Kathryn S. Young ${ }^{1}$, Svjetlana Curcic ${ }^{2}$ \\ ${ }^{1}$ Department of Teacher Education, Metropolitan State University of Denver, Denver, USA \\ ${ }^{2}$ School of Education, University of Mississippi, Oxford, USA \\ Email: kyoung42@msudenver.edu, scurcic@olemiss.edu
}

Received November 30 ${ }^{\text {th }}$, 2012; revised March $14^{\text {th }}$, 2013; accepted March 22 ${ }^{\text {nd }}, 2013$

Copyright (c) 2013 Kathryn S. Young, Svjetlana Curcic. This is an open access article distributed under the Creative Commons Attribution License, which permits unrestricted use, distribution, and reproduction in any medium, provided the original work is properly cited.

\begin{abstract}
Educational policy and practice have long been disconnected. This paper explores the experiences of two former teachers turned teacher educators as they examine unintended consequences of policy reform. This paper positions No Child Left Behind's and Individuals with Disabilities Education Act's "Highly Qualified Teachers," "Annual Yearly Progress," and the issues of "evidence-based practices” alongside the authors' personal school-based examples to demonstrate (dis)connections between policy, schools, and classrooms. The analysis provides a critique of these policies to demonstrate where teacher educators can take an active role in helping future teachers understand implications of these policies.
\end{abstract}

Keywords: Special Education; Teacher Education; Policy; No Child Left Behind; Highly Qualified Teacher; Annual Yearly Progress; Evidence-Based Practices

\section{Introduction}

Teacher education lies at the intersection between policy and practice. Teacher educators are often called on as part of state and federal educational committees. They act as a conduit for understanding how policy affects schools and teachers, and can help determine future policy directions as well. This paper highlights both authors' experiences as teachers and as teacher educators in order to provide experiential accounts of policies, and pitfalls with these policies, in action.

Specifically, we examine current policies that seek to ameliorate this divide by providing "researched-based practices" as a response. The growing (dis)connection between research and practice is evident in examination of No Child Left Behind's (2001) and Individuals with Disabilities Education Act's (2004) "Highly Qualified Teachers,” “Annual Yearly Progress,” and examination of "evidenced-based practices." Although some parts of NCLB and IDEA were developed from a researchpractice connection, with some findings in contention, there are also unintended consequences and disconnections between these policies and real classrooms with real teachers and students. These consequences are not often well defined in the research literature.

Before we turn to current policy initiatives, we offer a short historical summary of prior educational policy initiatives. Current educational policy arises from what was determined to be failed educational polices during the Great Society of the 1960s and 1970s (Rogers \& Oakes, 2005; Sarason, 1990). Technicalfocused equity reforms like desegregation and compensatory education were determined to have "no-effects findings" (Darling-Hammond, 1990; Rogers \& Oakes, 2005) leading the public and policy makers to believe that these policies did not work. The result of no-effects findings led to greater regulation which attempted to create greater adherence to policy initiatives by schools or to remove support from schools that did not adhere to new initiatives (Darling-Hammond, 1990; McLaughlin, 1987). In order to achieve greater articulation and adherence of these policies to practices a "cadre of professional 'change agents' seeking to help educators implement researched-based 'effective schools'” arose (Rogers \& Oakes, 2005: p. 2184). These change agents hoped to convey educational improvements to schools and school districts. Rogers and Oakes provide examples of change agents as educational consultants and of those who push for "large-scale systemic reform designed to align curriculum, teaching, and assessment, and school 'restructuring', (p. 2184). Systemic reforms include privatization in the form of vouchers and school choice and an intense rise in researchbased practices with catchy titles like Reading First, Response to Intervention, Read 180, and Everyday Math-all with the hope of aligning curriculum, teaching, and assessment. This "era of accountability” links alignment of curriculum, teaching and assessment to these educational reforms and to school improvement (King, 2006). It is hoped that testing, as the predominant measure of accountability, will also "raise organizational and instructional capacity” in schools (Greenlee \& Bruner, 2001: p. 2) and "serve to influence the teaching-learning process” (King, 2006: p. 27). In this paper we argue that the theory of action from accountability to attainment is not so linear and abounds with implementation tensions. We use institutional theory to help explicate some disconnects we experience(d) between policy and practice.

Institutional theory helps explain why policies do not "trickle down" as intended and instead become "rationalized myths" where policies are implemented as a veneer of change rather than actual educational change (Meyer \& Rowan, 1977). For 
example, one myth behind NCLB is that greater accountability of schools coupled with tighter sanctions will improve students' academic achievement. Policies, as rationalized myths, depend on "the fact that they are widely shared, or have been promulgated by individuals or groups that have been granted the right to determine such matters" (Scott, 1983: p. 14). NCLB has been rationalized through promulgation and political backing from both houses of Congress as well as from local actors like school boards and parent groups. NCLB has gained "social legitimacy" in the eyes of insiders and outsides alike (Scott, 2004).

Myths of accountability have become so taken-for-granted that they become acceptable norms in schools and in society (Bowker \& Star, 1999). It is difficult to argue with these groups who argue that schools should be accountable for children's learning - that part seems quite rational. However, Ellison and Kritsonis (2006) quote English (2003) in a cautionary note, as saying the "data driven" movement is based on the assumption that "hard data will provide a quantitatively and qualitatively better base and framework for decisions which will lead to improved (more accurate, timely, reliable) decisions” (p. 3). Institutional theory provides a frame for examining policies, procedures, and curricula in relation to claims of accountability and improved student learning often found in the rhetoric supporting NCLB because it entails a myth - a veneer of educational change-where there is little evidence that demonstrates how schools truly operate differently than before.

Another example shines through in the work of Grubb, Kinlaw, Posey, and Young (2011) who examined twelve cases of elementary and secondary schools that were working to improve educational outcomes for their low performing studentsmostly through the intensification of reading and math instruction. These schools were trying to meet NCLB mandates. Grubb and colleagues found that many of the schools adopted a "more of the same" approach to improving student learning. Students received "more" reading or math instruction, not instructionally innovative strategies for learning math and reading. In Grubb et al.'s study, the schools employed reading and math strategies that were sanctioned by the state, thus legitimizing those educational changes. However, because the strategies were not innovative, they just promulgated the rationalized myth of a veneer of educational change without truly enacting teaching and learning differently.

More than twenty years ago Darling-Hammond and Wise (1981) began exploring teachers' responses to educational policy. They and their colleagues found that policy can never be implemented as written because of institutional and personal responses to that policy (Darling-Hammond, 1990; Elmore, 1983; Spillane et al., 2002). This paper provides analysis of three seemingly well-intended policy initiatives and the ways they "trickled down" to schools and classrooms. The two authors of this paper, both former special educators and now teacher educators and educational researchers, provide their own experiences and understandings as teachers, teacher educators, and educational researchers of how educational policies affected our classrooms and those we visit and observe. Even though other studies examine these factors, this study demonstrates tensions we as teachers, and classroom observers, felt and continue to feel as we try to understand and implement new policy directives (Cohen \& Spillane, 1992; Weatherly \& Lipsky, 1977). These tensions highlight micro-occurrences that complicate policy adoption in real schools. These tensions also provide an ideal forum for teacher educators to examine these issues with each other and with their students.

\section{Policy and Practice Disconnection-A Legacy}

Disconnection between educational policy and practice is not new. Elmore and McLaughlin (1988) examined federal educational reform policies of the 1950s and 1960s like curriculum development in math, science, and social studies, compensatory education for students in grades K-3, and monetary incentives to improve academic performance of low-income youth to determine the mistakes made by policymakers in education policy implementation. More than 20 years after their study and 60 years after the policies they analyzed, we still struggle with many of the same issues and what policies might have an effect on entrenched schooling practices and on students' academic results. Hallinan (1996) takes a second tack and points to the different agendas of researchers, policy makers and practitioners. Researchers are "slow and cautious in presenting findings" while "school personnel are faced with immediate and pressing demands to manage their schools, make policy decisions, and design school programs” (p. 133). Honig (2006) points in a third direction to research on district central office administrators as potential allies but more often demonstrates how the central office acts as a barrier in implementing new policy because of a lack of institutional support at the district level. In addition to levels of disconnect, continues the pervasive question on what sorts of educational changes do we want? What do we do when we cannot reach consensus on type of change or how to implement it? (Keogh, 1990).

One notable study that contradicts previous findings of institutional decoupling-where schools respond to pressure from policy by divorcing changes in structures from classroom instruction-is that of Coburn (2004). She argues that policy does reach within schools to influence classroom practice but that teachers have a role in mediating the policy guidelines through their "preexisting beliefs and practices" which are "rooted in past encounters with institutional pressures." She continues, "This process is influenced by the nature of the institutional pressure-its congruence with teachers' preexisting beliefs and practices, its intensity, its pervasiveness, and its voluntariness." (Coburn, 2004: pp. 211-212).

Coburn's argument helps us explain the disconnect we, the authors, felt as classroom teachers trying to implement No Child Left Behind's and Individuals with Disabilities Education Act's "Highly Qualified Teachers," "Annual Yearly Progress," and "evidence-based practices". In many ways, the following sections highlight these policies' congruence or incongruence with our preexisting beliefs and practices and the intensity, pervasiveness, and lack of voluntariness of the new policies.

\section{Highly Qualified Teacher}

The recent reauthorization of the Individuals with Disabilities Education Improvement Act (IDEIA) of 2004 ("Individuals with Disabilities Education Act,” 2004), and of NCLB (2001) prescribed a definition of "Highly Qualified" special educator as the one who: (1) Holds at least a bachelor's degree from a four-year institution; (2) Holds a full state credential; and (3) Demonstrates competence in their subject area.

Veteran teachers are not considered highly qualified unless they demonstrate subject knowledge through coursework, testing, or "high, objective, uniform state standards of evaluation" 
(HOUSSE) determined by each state (US General Accounting Office, 2004).

At first glance the definition of Highly Qualified Teacher (HQT) makes sense, which helps it gain legitimacy as a part of new educational policy. However, we present several personal scenarios that indicate HQT to be part of a rationalized myth. The US Department of Education recognizes "alternative routes" to credentialing such as "Troops to Teachers" and "Teach for America" with college students placed into classrooms while they are completing teacher education and certification programs. Why these individuals would be considered highly qualified as long as they are "participating in a qualifying alternative route program while teaching," (US Department of Education, 2003: p. 6), as opposed to veteran teachers who have completed teacher preparation programs is not clear and scratches at the veneer of this rationalized myth. It is also not clear how such arrangements differ from teachers who were teaching on emergency credentials, while completing teacher education programs, arrangements which are no longer acceptable. Both groups, veteran teachers and college students, have to eventually prove their competency through exams. Surprisingly, however, college graduates are considered highly qualified as soon as and as long as they participate in an alternative certification program, while veteran teachers who have college degrees and a teaching license already, will only be highly qualified upon completion of the HOUSSE steps as determined by each state. Determining "highly qualified" strictly according to policy gives scenarios like the one below, where someone with extensive experience is not deemed highly qualified, though a person in the same teaching position who was completing an alternative route would be highly qualified.

Scenario \#1: Highly educated and experienced but not "highly qualified"

(West coast high schools, Resource room, 1999-2002—Second author)

When I started a career as a special education teacher, I already had completed a doctoral program (Ed. D.) and worked for years with students with disabilities. None of this contributed to making me a teacher then, or would make me a "highly qualified teacher" now. As my doctoral program was not a teacher credential program, and my experience was not in public schools, I then engaged in completing a teacher credential graduate program in Mild/Moderate disabilities, just one of the many prerequisites on the way to becoming a special education teacher. Equipped with all this knowledge, coupled with experience of working for years with students with disabilities, I finally one day appeared enthusiastically in the Resource room in a public school, for my first class in the first period. To my surprise, thirty students with learning disabilities showed up in the first period, one student in the second period, and varied students in numbers and grades in the periods to follow. It took almost a month to make different schedules for the students, a job of the counselors, as I learned in the process. My new highly qualified status did not prepare me for any encounters with school bureaucracy (A similar experience happened a year later in another school, in another state).

Within the current education framework one can be qualified to teach future teachers but not present students as in Scenario \#1. This example highlights tensions in the meaning of "highly qualified" with lived school experiences. The focus in education, as well as in educational reforms, is predominantly on teachers, and rightly so, because they are at the heart of the education process. To hold HQT as the professional bar but then expect any teacher to be prepared for institutional bureaucracies that put student learning behind institutional scheduling is setting the teacher and students up for failure. It also sets the policy up for people to question its relevance in the real classroom.

Kelchtermans and Ballet (2002) acknowledge the role of institutional politics in the ability of teachers to teach better in schools. They argue that teachers need to be well-versed in micropolitical literacy as an important part of professional development. Micropolitical literacy includes "three aspects: the knowledge aspect, the operational or instrumental aspect and the experiential aspect" (citing Kelchtermans \& Vandenberghe, 1996). The knowledge aspect entails knowing how to read a situation. In relation to policy, this would include future teachers' being well versed in practical implications of policy implementation. The operational aspect includes a teacher's repertoire of effective strategies for enacting the roles they will be asked to fill in schools given new policy imperatives. The experiential aspect of practical implications for policy mandates would indicate how (new) teachers feel about the new policyfrom powerlessness and anger to joy and acceptance. This aspect often requires future teachers to react in some way to their changing role in schools, like knowing what to do when teachers' schedules change rapidly at the beginning of the school year.

Using strategies and understandings from micropolitical literacy is one way to keep new teachers teaching and to help them truly become more qualified at their positions by preparing them with knowledge about the rest of the school organization that provides a more complete picture of schools, more opportunities to find the human or physical resources they may need, and a better understanding of the politics of teaching. Curry et al. (2008) use the idea of micropolitical literacy to further their work with mentors and new teachers in an inquiry based professional development program that works to create positive change in urban schools. Participants of this program report that they have been "inspired... to improve their teaching and hold fast to the ideal of making a difference for kids and society" (Project IMPACT website

http://www-gse.berkeley.edu/admin/ExtRel/impact.html). This project works to keep new teachers teaching so that urban schools do not lose one third to one half of their new teachers in the first five years of teaching. It works with new teachers to "effectively contribute to school reform" and "advance transformative, critical visions of education” (Curry et al., 2008: p. 660).

Micropolitical literacy asks more of new teachers than proper degrees, credentials, and subject competence to lead students to academic success. It provides context for new teachers to examine policy initiatives in practice. Micropolitical literacy is being examined as one way to further teacher professional development and longevity in the classroom and can become part of what is asked of "highly qualified" teachers. Teacher educators must not only focus on developing "highly qualified" teachers as the law has determined, but also teachers who understand that teaching is highly contextualized and may be highly political if they are to stay in the field and increase their teaching competence (Blase, 1997; Kelchtermans \& Ballet, 2002; Kuzmic, 1994).

The next example "Highly qualified by whom" contrasts the previous one "Highly educated and experienced but not highly 
qualified". In the previous scenario a person with extensive experience and success with pushing students academically is not highly qualified while in this example a person with little experience and lack of academic success with students is considered highly qualified. Both teachers need to better understand the micro-politics of their situations to be better suited to accomplish the task at hand and work well with students in schools.

Scenario \#2: Highly qualified: by whom?

(November, 2005 West coast high school—First author)

I witnessed a self-contained class for students with moderate disabilities where the teacher was more focused on students feeling good than with teaching them academic content. It took almost two years of working with the teacher to have him decide that teaching high school students with disabilities about fuzzy animals and the holidays was not an adequate curriculum. This teacher was in the process of becoming a "Highly Qualified Teacher." He did extremely well in course work but did not bring this intellectual stimulation to his classroom. His school district supported his methods because he kept students out of the office, parents happy, and paraprofessionals without complaints. According to everyone but me, he was a highly qualified teacher-but the problem was that he was not teaching students. If he had a different university supervisor, it is likely that his methods would have passed as acceptable and he would have reached the designation without educating his students in a highly qualified manner.

The teacher's students were not receiving the best education they could, not even a very good education by some accounts. Although the school felt this individual was highly qualified by meeting the federal definition, he did not provide quality instruction to students. This example demonstrates a disconnect between policy initiatives like highly qualified teacher and what actually happens in schools-where a teacher who pleases the administration is highly qualified (Another teacher at the same school, who worked on including his students in general education, and had all but one student pass the high school exit exam was "let go" by the same administration because he did not get along with several key players at the school).

These two scenarios highlight a policy/practice disconnect between the federal definition of Highly Qualified Teacher and examples from lived experience. These scenarios help to demystify HQT and help explain why endorsement of HQT as a rationalized myth is not adequate for improving teaching and learning in schools. One way to address this disconnect is through adoption of a micropolitical lens with preservice and inservice teachers so they can move beyond definitions to thinking and then acting differently in the classroom.

\section{Annual Yearly Progress (AYP)}

Teachers, and especially special education teachers, are in an unenviable situation described by Castell half a century ago in terms of data driven progress monitoring in schools (in Barzun, 1959). He noted that since the scientific observation of children had discovered norms of development, these should determine the time and the way any subject is taught. Yet, it had also been noted that each child should set his or her own pace-which Castell termed "blowing hot and cold" in relation to research, policy, and practice (in Barzun, 1959: p. 104). Developmental exceptions are not embraced by statistical norms; consequently, there is a tension between assessing students against norms and letting each student progress independently.

While using data is not a new concept, what is new in NCLB is the idea to use averaged data for subgroups in order to determine whether a school is making adequate yearly progress (AYP), or whether a school is failing. If a single group, for example students with disabilities or students with limited English proficiency, falls short of a target set against the (arbitrarily chosen) year 2014, that school may be designated as failing. As Darling-Hammond (2004) points out, these subgroups (e.g., students with disabilities, English language learners) were created because some students do not meet the "norm" standards in the first place. Consequently, the schools might not meet their AYP goals. As a result, those schools that educate students with learning difficulties may end up being penalized for their efforts to educate them. The NCLB policy therefore creates competing objectives.

With the accountability turn in policy, we are back to the discovered norms of development and using data to determine performance. This system forgets that there are those students who will not fall in the middle of the distribution, which is one of the reasons why some students, with a specific learning disability in reading for example, will not read at grade level by 2014 as required by No Child Left Behind. Expecting the same results from all students on the state tests is in direct tension with most Individualized Education Programs (IEPs) of students with disabilities and is impossible given statistical norming.

The tension between $100 \%$ of students making Adequate Yearly progress (AYP) and meeting individual needs at the pace individuals need to progress looms large for teachers in schools. In this respect, the IDEA goals with a focus on individual needs of students established in their IEPs and NCLB goals with testing and evaluating students against the same standards contradict each other. On one hand, tracking the progress of students through a mechanism like AYP is a welcome goal of accountability in the field of education. On the other hand, using the averaged student subgroup data to penalize schools is an unfortunate outcome that does not increase student learning. This tension frames the following scenario and brings into question how legitimate is this part of the rationalized myth that assessment data lead to improved student outcomes.

As special education teachers, we regularly received data on our students' performance on state-mandated tests. The data usually came in numbers for math, reading and writing. An important question about the data is: How did these numbers inform our instruction? The short answer to that question is: not much. What informed our practice was daily attention to our students' work and progress. Data from state tests come towards the end of the semester or sometimes the end of the year. Waiting and relying on one score would be a disservice to students. Teachers, fortunately, do not rely on one score and conduct their own assessments.

Skrtic (1995) noted more than a decade ago that educational policy discourse reflects naïve pragmatism dominated by those concerned primarily with efficiency. The US is not alone in that respect: studies that extend beyond the borders of the US note an increased policy attention to clinical and managerial aspects of education, focused on accountability, school evaluations, individual diagnosing, and school choice (Simola, Rinne, \& Kivirauma, 2002). There is less of a focus on how to decrease adverse effects for those deemed culturally "different" or eco- 
nomically worse off than the average student (Johannesson, Lindblad, \& Simola, 2002). On the contrary, there may be some indication that such students may be pushed to exclusion (e.g., Wood, 2004). Through examples from different US states, Wood (2004) points out how real graduation numbers can be correlated with a similar rise in the students who are being retained in grade level for more than one year (e.g., "Texas miracle”) and increased drop-out rates (e.g., Illinois) (pp. 36-38). The next scenario illustrates how a policy like AYP affects educational decisions teachers make in their classrooms.

Scenario \#3: AYP and Inclusion

(October, 2007 Southwest middle school—First author)

I observed lessons in an inclusive middle school in an inclusive district where I witnessed good teaching. It was not obvious who had and who did not have a disability in many classrooms. In this school, I also observed a teacher reprimand a student (who is considered "at-risk" or to have ADHD, no one knew which) who was acting silly with his peers. I had already heard his name called out several times. This student had spent more than $80 \%$ of his time in class doing what he was supposed to but without notice from the teacher. When she did notice, he was sent to the hall, where he slouched over and kicked his textbook under his feet until he got outside the door and slumped to the floor.

In another class, students were practicing mapping their classrooms. A little boy (with no apparent disability, but he certainly would be considered "at-risk" in this environment) in the class was reprimanded several times (for offenses I did not witness even though I sat less than three feet from him). The third time he was told he would be staying after school for detention and needed to call home to tell his guardians about it. Immediately, he shut off. He folded in on himself and his eyes became vacant. For the next twenty minutes this child did nothing and no one noticed.

The above middle school is under intense pressure by the state and federal government because they have not made "Adequate Yearly Progress" for two years in a row, even though they have been making academic gains with students. This school's response to try to meet the demands of No Child Left Behind's (2001) AYP was to send disruptive students into the hall so the rest of the students had more time to learn resulting in the students who most need instruction (disabled or not) becoming disengaged from it. Though we can see why a teacher might not want a student to be disruptive in class, removing the student from any chance of academic engagement will not increase that child's performance on standardized testing and does not bode well for increasing school-wide AYP if this is a pervasive school practice. When I (first author) brought up this experience with my teacher education students, they felt the teacher was justified in excluding those children from the classroom. It was only upon probing for deeper understanding did some students begin to see the systemic nature of student exclusion (Skiba, Simmons, Ritter, et al., 2006). They moved from feeling justified to remove students who impacted others' learning, to wondering how to better engage those children in the classroom and the learning process. In reporting about disciplinary exclusions, Head, Kane, and Cogan (2003) noted that many teachers in their study recognized that difficulties did not reside within the students but rather within the curriculum. This recognition shifted the focus on cooperation between learning support staff, classroom teachers, and students toward cooperative teaching and further curriculum development.
Adequate yearly progress threatens to become another veneer of change if schools choose options that remove students from the classroom for disruptive behavior rather than reexamine curricular choices as a way to keep children engaged and in the classroom. In a chapter titled "Reimagining special education," Florian (2007) advocates examining the potential for student academic progress in relation to "the fulfillment of the right to education, the challenge to deterministic beliefs about ability, and a shift in focus from differences among learners, to learning for all” (p. 18). Hart et al. (2004) argue for the teacher's responsibility to enact curriculum differently so they no longer have to focus on problems with students, but instead think through problems for teaching.

This reinvisioning of schooling would lead to very different classrooms where the definition and expectation of student progress goes further than scores on standardized tests to authentic learning in classrooms for everyone and reduces the need to exclude some students so that others may learn.

\section{Improving Education through AYP and "Evidenced-Based Practices"}

Our discussion in this section is limited to some under-examined assumptions that are present in NCLB and IDEIA policy and are offered as a legal guide to the improvement in the field of education. These assumptions include legislation related to school choice and AYP, Response-to-Intervention (RTI), and evidence-based practices. We examine these provisions through the lens of legitimated policies that often affect practice differently than might be expected in policy circles.

Under the provisions of NCLB, schools that fail to make adequate yearly progress (AYP) toward meeting state goals are eventually subject to restructuring, which may include turning the operation of the school over to a private company or allowing students to transfer to another school that is making AYP at a cost to the first school. In 2002-03, nearly 50 private companies managed over 400 public schools in 25 states. The US General Accounting Office (GAO) (2003) compared standardized scores on mandatory state tests of students attending public schools with scores of students attending privately managed schools that had been in operation for four years or more in six large cities. Fourteen privately managed schools in Cleveland (Ohio), Denver (Colorado), Detroit (Michigan), Phoenix (Arizona, St. Paul (Minnesota), and San Francisco (California) were matched with two or more traditional public schools in the same city that were similar in terms of grade span, enrollment, student race and ethnicity and the percentage of students with English language learners, disabilities, and eligibility for the federally subsidized free and reduced price school lunch program (GAO, 2003: p. 2).

The GAO findings indicate that there was no significant difference between privately managed schools and public schools; some had equal performance, some better and some worse than the public schools measured on reading and mathematics tests. The school sample was not small but it was limited and strong conclusions are not warranted. However, also not warranted is the idea that school choice will contribute to a better education for some students who may opt to transfer to another school or that they might even have such an option. This is part of the rationalized myth that privatization leads to higher academic proficiency. For example, in 2002 only 10\% of eligible Chicago students requested transfers, and half of them were denied due 
to lack of space in receiving schools (Borkowski \& Sneed, 2006: p. 509). They further their claim by citing evidence from The Civil Rights Project (CRP) at Harvard University. CRP conducted research in eleven urban school districts where only $3 \%$ of eligible students transferred to other schools (Borkowski \& Sneed, 2006: pp. 508-509) which leads one to question the legitimacy of legislation that allows children to "opt" for better schools if that option is limited in realities of implementation. Finally, student placement should be viewed in the context of another report cited by Borkowski and Sneed (2006), that of the US Department of Education in 2006, confirming that students in public schools generally do just as well as students in similar private schools (p. 509). Therefore the veneer of change that indicates "choice" and privatization as mechanisms of school improvement tarnishes when examined more closely.

Of particular interest to us, as special educators, is the reauthorization of IDEA in 2004, renamed "Individuals with Disabilities Education Improvement Act of 2004” (IDEIA). The IDEIA changed the way we determine whether a student has a learning disability. On August 16, 2006, the US Dept. of Education issued extensive commentary to accompany the final IDEIA on LD regulations. One of the changes described in paragraphs 300.304 through 300.306 is the reliance on data. Data should demonstrate that prior to, or as a part of a referral process, the child was provided appropriate instruction in a regular education setting, and secondly, that the repeated assessment of achievement at reasonable intervals was also databased. The IQ discrepancy model is no longer required but instead "in determining whether a child has a specific learning disability, a local educational agency may use a process that determines if the child responds to scientific, research-based intervention as a part of the evaluation procedures as described in paragraphs (2) and (3)" (IDEIA, 2004, Public Law 108-446, 2004). What constitutes "appropriate" and how many assessments of progress should be conducted in regular education setting, has not been specified. There are requirements for comprehensive evaluation without relying on any single criterion for determining eligibility. However, the focus in practice seems to be away from "comprehensive" and decisively toward RTI (e.g., ISBE, 2008), although RTI may not be the sole determinant of whether a child meets LD eligibility (IDEIA, paragraph 300.304.b). Again, policy, when not well paired with practice leads to disconnects. "Comprehensive evaluation" in policy becomes "response to intervention” in practice.

RTI already means different things to different groups of people. For example, some general education teachers see this initiative as a special education job (since originally it offered another means of classifying students with disability), while some view this initiative as a general education initiative (as the implementation is envisioned to start in general education setting). At the same time, many schools are adding early reading programs as RTI interventions. Gamse, Bloom, Kemple, and Jacob (2008) conducted the first impact study on Reading First, a congressionally mandated evaluation of the governmentsponsored initiative to help children read. The study examined 18 sites across 12 states and the impact of Reading First, considered "scientifically based" instructional model. Gamse et al. (2008) findings indicate that Reading First did not improve students' reading comprehension. The program did not increase the percentages of students in grades one, two, or three, whose reading comprehension scores were at or above grade level. In each of the three grades, fewer than half of the students in the
Reading First schools were reading at or above grade level. However, in some states such as Illinois, for example, the Illinois State Board of Education (ISBE), has concluded that the Reading First schools improved student reading by 20\% (ISBE, 2008). For a scientifically based reading program such discrepancies are not something to be expected.

In Illinois, Reading First was combined with the tiered three approach to instruction (students provided with intensive reading instruction). The $20 \%$ gain in Illinois reading gain was shown on Dynamic Indicators of Basis Literacy Instruction (DIBELS). Many states receiving federal Reading First funds have been mandated to use DIBELS for the purposes of monitoring students' reading progress in early grades (K-3). Although DIBELS seems to be widely used, Schilling, Carlisle, Scott and Zeng (2007) suggest supplementing DIBELS with measures of reading comprehension. In their study from first through third graders attending 44 schools in 9 districts or local educational agencies that made up the first Reading First cohort in Michigan, they concluded that DIBELS at-risk benchmarks for oral reading fluency (ORF) were reasonably accurate at identifying second and third graders who were reading below the twenty-fifth percentile at the end of the year (80\% and $76 \%$ for second and third graders, respectively) (We do not know whether the teachers might have been reasonably accurate at predicting at-risk students as well, if asked). However, $32 \%$ of second graders and $37 \%$ of third graders who were identified as at low risk in the fall by the ORF benchmarks turned out not to be reading at grade level on the Iowa Test of Basic Skills (ITBS) in April. There are further concerns that DIBELS measures fluency (or speed) without taking into consideration comprehension and therefore may lack predictive validity. Pressley, Hilden and Shankland (in revision) conducted a study with 191 early elementary students taught by 10 teachers in four different schools. They concluded that DIBELS is "at best a measure of who reads quickly without regard to whether the reader comprehends what is read" (p. 1). Both the instructional program (Reading First) and the way it is evaluated in the schools (DIBELS) raise concerns about the meaning of evidence-based practices.

\section{Discussion}

As examination of policy initiatives-Highly Qualified Teachers, Annual Yearly Progress, and evidence-based practices points out, policy solutions are without enough implementation support or realistic accounting of schools and schooling to fully realize their goals. Meyer and Rowan (1977) would argue that creating new policy initiatives rationalizes the myth that teaching and student achievement will improve because of the new initiatives. We argue that schools will never improve with weak, contradictory, and under funded initiatives that do not reexamine teaching and learning in an in-depth manner. Schools will improve with policies that are well aligned with multiple stakeholders' needs and are well supported at every level of government. These policies must be well understood by schools and teachers and demonstrate to teachers, parents and students how learning on multiple fronts is progressing (Guilfoyle, 2006).

Schools want highly qualified teachers, students who make adequate yearly progress, and teachers to use evidenced based practices. However, as former teachers and current teacher educators and educational researchers, we question these reified 
catchy phrases and the policies they represent. We have spent and continue to spend time in schools where we daily confront practices that represent more of a veneer of educational change than schooling done differently.

States want highly qualified teachers. They always have. States must also find ways to fill their classrooms with teachers - no matter the qualification. M. Pugach (personal communication, October 11, 2007) pointed out that in order for high school special educators to become highly qualified, they must teach only the subject they are qualified to teach. For those teachers who continue to work in self-contained classrooms, they will need to be highly qualified in English, Math, Social Studies, and Science. Special education is the only content area where Highly Qualified is nearly impossible to meet and where one teacher is expected to be highly qualified in so many content areas. We do not advocate for lowering the standards for hiring and credentialing good teachers, but we are and should be wary about terms like Highly Qualified and how best to meet such policy expectations while not sacrificing quality for bureaucratic adherence in schools.

The AYP mandate does bring attention to groups that historically have performed poorly in school and demands that these groups not be overlooked. It also implicitly encourages schools to craft instruction differently for different subgroups of children. The policy could encourage innovative practices, but because of the heavy threat of sanctions, innovation is shelved in favor of looking for loop holes or adhering closely to the law to avoid sanctions (Guilfoyle, 2006; Schoen \& Fusarelli, 2008). AYP also implicitly encourages schools to move to choice plans where not only parents, but schools, can choose which children to educate. The schools will have added incentive to choose to accept children who will perform better on the tests, and to also turn away students with disabilities or students who are learning English, especially since many schools that are meeting AYP are already full or close to full (Borkowski \& Sneed, 2006; Figlio \& Getzler, 2002).

\section{Implications for Teacher Preparation}

As schools and policy makers continue to make "technical focused equity reforms” (Rogers \& Oakes, 2005) we will continue to see the same students failing in schools. Ryan (2004), points out that though No Child left Behind has "laudable goals" it is structured in such a way that choice based schools are incentivized to exclude "African American, Hispanic, and poor students" because "these students traditionally do not perform as well as their white and more affluent peers on standardized tests" (p. 961). As members of Congress continue to weigh revisions to No Child Left Behind, this is a time to look to those who offer alternative solutions and possible ways forward within teacher education and educational policy more broadly.

Kelchtermans (2005) critiques the increasing performativity of schooling. He notes that schools have become "a whole series of technologies and procedures: standards and standardbased testing, audit procedures and methods for self-evaluation, etc. In some countries this has resulted in league tables of schools, high stakes testing, scripted curricula...” (pp. 2-3). He argues that performativity has reshaped the relationships in schools and that "performativity results in a reductionist conception of education" (p. 4). He asks educational researchers and teacher educators to ask ourselves "where are we as re- searchers in this? If we don't want to simply be accomplices, we have to critically ask whether and in what respect our activities as researchers, teachers and teacher educators contribute to the negative impact of that performativity?” (p. 5).

We focus here on some aspects of teacher preparation programs and the ways they could better meet the needs of future teachers. Literature that recognizes the advantages of schools conceptualized as learning organizations has begun to accumulate (cf., Silins, Zarins, Muliford, 2002). Yet, most teacher education programs prepare teachers to become individual professionals rather than members of some future team. One way to integrate teachers into all aspects of school functioning is to think about schools as learning organizations. Some of the most frequent descriptors of schools as learning organizations are: shared vision, cooperative and team learning (often times advocated as an approach to teach students but not practiced by teachers), and the sense of "interconnectedness of the parts and... contribution to the direction in which the school is heading” (Silins, Zarins, \& Mulford, 2002: p. 29). Elmore and McLaughlin (1988) advocate the following:

(1) charge practitioners with the development of solutions rather than mandating requirements that have little or no basis in practice; (2) accommodate variability be creating policies that lead to better understanding of effective practice rather than discouraging and penalizing it; (3) learn that rules only set the standards of fairness and do no prescribe solutions to practical problems; and (4) create organizations that foster and encourage reforms of practice (p. vii).

An example of these types of practitioner driven reforms that bring policy and practice closer together is that of the possibility of examining school vision in relation to zero tolerance policies. Many schools have adopted zero tolerance policy as if a strict school policy will remove problematic behaviors. Suspensions lead to less instructional time for students and less instructional time is not likely to increase schools' performance on AYP. Teacher education programs must also examine the unintended consequences of curricular decisions about where to place conversations about students' behaviors. Teacher preparation programs often teach classroom management as a separate course as if classroom management happens in a vacuum. A more productive route would be to focus on teaching how to increase student engagement through the curriculum. After shadowing students qualified as "severely emotionally and behaviorally disturbed” (SEBD) over one academic year, Hamill and Boyd (2001) reported that in classes with occurrences of challenging behaviors, the behaviors were just as likely to involve students who were not qualified as SEBD as those labeled SEBD. Although there are studies on student engagement and motivation (e.g., Guthrie, McRae, \& Litz Klauda, 2007), these aspects of students' learning are much less researched (Troia, Shankland, \& Wolbers, in press) and taught in teacher education programs than other aspects of learning, divorcing academics from behavior.

Finally, Rogers and Oakes (2005) caution us not to rely only on those within the professional educational community for reform. In their paper exploring what John Dewey might say about "Research, democratic social movement strategies, and the struggle for education on equal terms" they remind us that Dewey was reliant on activism from teachers, not the masses. Rogers and Oakes borrow from Cornel West in remarking that participatory social inquiry can only occur where professionals and the public work together to create reform. They argue that 
teachers often "hold themselves above and apart from workers," but to make lasting equity-based reforms teachers must work in conjunction with "the masses" (Rogers \& Oakes, 2005: p. 2194). In the 1930s John Dewey became disillusioned with professional educators' willingness to advocate for political (and educational) change because "powerful interests could use mass communication to distort and subvert public understanding” (Rogers \& Oakes, 2005: p. 2179). Eighty years later these "powerful interests" are still at work. Finally, we suggest focus on envisioning teacher education as a conduit for policy, examining teacher education as a mirror for policy, placing teacher education as a stakeholder and creator of policy, and partnering teacher preparation with schools, teachers, parents, and students. These ideas are not new but merit repetition since they are not at the forefront of ideas forwarded by the "powerful interests" of today.

\section{REFERENCES}

Barzun, J. (1959). The house of intellect. New York: Harper Collins Publishers.

Borkowski. J. W., \& Sneed, M. (2006). Will NCLB improve or harm public education? Harvard Educational Review, 76, 503-727.

Bowker, G., \& Star, S. L. (1999). Sorting things out: Classification and its consequences. Cambridge, MA: MIT Press.

Coburn, C. E. (2004). Beyond decoupling: Rethinking the relationship between the institutional environment and the classroom. Sociology of Education, 77, 211-244. doi:10.1177/003804070407700302

Cohen, D. K., \& Spillane, J. P. (1992). Policy and practice: The relations between governance and instruction. Review of Research in Education, 18, 3-50.

Curry, M., Jaxon, K., Russell, J. L., Callahan, M. A., \& Bicaise, J. (2008). Examining the practice of beginning teachers' micropolitical literacy within professional inquiry communities. Teaching and Teacher Education, 24, 660-673.

doi:10.1016/j.tate.2006.10.007

Darling-Hammond, L. (1990). Instructional policy into practice: "The power of the bottom over the top". Educational Evaluation and Policy Analysis, 12, 339-347.

Darling-Hammond, L. (2004). From "Separate but Equal” to "No Child Left Behind”: The collision of new standards and old inequalities. In D. Meier, \& G. Wood (Eds.), How the no child left behind act is damaging our children and our schools: Many children left behind (pp. 3-32). Boston: Beacon Press.

Darling-Hammond, L., \& Wise, A. E. (1981). A conceptual framework for examining teachers' views of teaching and educational policies. Santa Monica, CA: RAND Corporation.

Ellison, E., \& Kritsonis, W. A. (2006). Making educational methods more lucrative: A postmodernist's perspective. National Journal for Publishing and Mentoring Doctoral Student Research, 3, 1-6.

Elmore, R. (1983). Complexity and control: What legislators and administrators can do about implementing policy. In L. S. Shulman, \& G. Skyes (Eds.), Handbook of teaching and policy (pp. 342-369). New York: Longman.

Elmore, R. F., \& McLaughlin, M. W. (1988). Steady work. Policy, practice, and the reform of American education (ED 296 020). Washington DC: National Institute of Education.

English, F. (2003). The challenge of postmodernism to the theory and practice of educational administration. Springfield, IL: Charles C. Thomas Publisher.

Figlio, D. N., \& Getzler, L. S. (2002) Accountability, ability and disability: Gaming the system. National Bureau of Economic Research, Working Paper No. 9307. http://www.nber.org/papers/w9307

Florian, L. (2007). Reimagining special education. In L. Florian, \& Sage Publications Inc. (Eds.), The SAGE handbook of special education (pp. 1-20). London, Thousand Oaks: SAGE Publications.

Gamse, B. C., Bloom, H. S., Kemple, J. J., \& Jacob, R. T. (2008). Rea- ding first impact study: Interim report (NCEE 2008-4016). Washington DC: National Center for Education Evaluation and regional Assistance, Institute of Education Sciences, US Department of Education.

Greenlee, B. J., \& Bruner, D. Y. (2001). State assessment rediscovered: Can accountability tests initiate better reading? Wingspan, 14, 2-5.

Grubb, W. N., Kinlaw, H., Posey, L., \& Young, K. (2011). Dynamic inequalities III: Exploring what schools do for low performing students. In N. Grubb (Ed.), The money myth: School resources, outcomes, and equity. New York: Russell Sage Foundation.

Guilfoyle, C. (2006). NCLB: Is there life beyond testing? Educational Leadership, 64, 8-13.

Guthrie, J. T., Mcrae, A., \& Lutz Klauda, S. (2007). Contributions of concept-oriented reading instruction to knowledge about intervenetions for motivations in reading. Educational Psychologist, 42, 237250. doi:10.1080/00461520701621087

Hallinan, M. T. (1996). Bridging the gap between research and practice. Sociology of Education, Special Issue on sociology and educational policy: Bringing scholarship and practice together, 69, 131-134.

Hamill, P., \& Boyd, B. (2001). Striving for inclusion: Evaluation of provisions for young people with social, emotional and behavioral difficulties (SEBD) in secondary schools in Scottish Council. Scottish Educational Review, 33, 142-156.

Hart. S., Dixon, A., Drummond, M. J., \& McIntyre, D. (2004). Learning without limits. Maidenhead, Berkshire, England: Open University Press.

Head, G., Kane, J., \& Cogan, N. (2003) Behavior support in secondary schools: What works for schools? Emotional and Behavioral Difficulties, 8, 33-42.

Honig, M. I. (2006). Street-level bureaucracy revisited: Frontline district central-office administrators as boundary spanners in education policy implementation. Educational Evaluation and Policy Analysis, 28, 357-383. doi:10.3102/01623737028004357

Illinois State Board of Education (ISBE) (2008). Response-to-Intervention.

http://www.state.il.us/video/streaming/isbe/response-to-intervention090408.asx

Individuals with Disabilities Education Act (IDEA), US Department of Education (2004).

Individuals with Disabilities Education Improvement Act (IDEIA) (2004).

http://thomas.loc.gov/cgi-bin/query/z?c108:h.1350.enr

Johannesson, I. A., Lindblad, S., \& Simola, H. (2002). An inevitable progress? Educational restructuring in Finland, Iceland, and Sweden at the turn of the millennium. Scandinavian Journal of Educational Research , 46, 325-339. doi:10.1080/0031383022000005706

Kelchtermans, G. (2005). Professional commitment beyond contract: Teachers' self-understanding, vulnerability and reflection. Keynote presented at the Bi-annual meeting of the International Study Association on Teachers and Teaching (ISATT), Sydney.

Kelchtermans, G., \& Ballet, K. (2002). The micro politics of teacher induction. A narrative-biographical study on teacher socialisation. Teaching and Teacher Education, 18, 105-120. doi:10.1016/S0742-051X(01)00053-1

Kelchtermans, G., \& Vandenberghe, R. (1996). Becoming political: A dimension in teachers' professional development. A micropolitical analysis of teachers' professional biographies. Paper presented at the Annual Meeting of the American Educational Research Association, New York (ERIC-Document ED 395-921).

Keogh, B. K. (1990). Narrowing the gap between policy and practice. Exceptional Children, 57, 186-191.

King, B. W. (2006). Relationship of principal's leadership behaviors to academic achievement and school improvement efforts. Unpublished Doctoral Dissertation, College Park: University of Maryland.

Kuiper, E., Volman, M., \& Terwel, J. (2005). The web as an information resource in K-12 education: Strategies for supporting students in searching and processing information. Review of Educational Research, 75, 285-329. doi:10.3102/00346543075003285

Kuzmic, J. (1994). A beginning teacher's search for meaning: Teacher socialisation, organisational literacy, and empowerment. Teaching 
and Teacher Education, 10, 15-27.

doi:10.1016/0742-051X(94)90037-X

McLaughlin, M. W. (1987). Learning from experience: Lessons from policy implementation. Educational Evaluation and Policy Analysis, 9, 171-178.

Meyer, J. W., \& Rowan, B. (1977). Institutionalized organizations: Formal structure as myth and ceremony. American Journal of Sociology, 83, 340-363. doi:10.1086/226550

No Child Left Behind Act (2001). Pub. L. No. 107-110, 107th Congress.

Park, S. H., \& Ertmer, P. A. (2007). Impact of problem-based learning (PBL) on teachers' beliefs regarding technology use. Journal of Research on Technology in Education, 40, 247-267.

Pressley, M., Hilden, K. R., \& Shankland, R. K. (2006). An evaluation of end-grade-3 Dynamic Indicators of Basic Early Literacy Skills (DIBELS): Speed reading without comprehension, predicting little. East Lansing, MI: Michigan State University, College of Education, Literacy Achievement Research Center (LARC).

Rogers, J., \& Oakes, J. (2005). John Dewey speaks to Brown: Research, democratic social movement strategies, and the struggle for education on equal terms. Teachers College Record, 107, 2178-2203. doi:10.1111/j.1467-9620.2005.00588.x

Ryan, J. E. (2004). The perverse incentives of the No Child Left Behind act. New York University Law Review, 79, 932-989.

Sarason, S. B. (1990). The predictable failure of education reform: Can we change course before it's too late? San Francisco: Jossey-Bass.

Schilling, S. G., Carlisle, J. F., Scott, S. E., \& Zeng, J. (2007). Are fluency measures accurate predictors of reading achievement? Elementary School Journal, 107, 429-448. doi:10.1086/518622

Schoen, L., \& Fusarelli, L. D. (2008). Innovation, NCLB, and the fear factor. Educational Policy, 22, 181-203. doi:10.1177/0895904807311291

Scott, W. R. (1983). Introduction: From technology to environment. In J. W. Meyer, \& W. R. Scott (Eds.), Organizational environments: Ritual and rationality (pp. 13-17). Beverly Hills, CA: Sage.

Scott, W. R. (2004). Institutional theory: Contributing to a theoretical research program. In K. G. Smith, \& M. A. Hitt, (Eds.), Great minds in management: The process of theory development (pp. 460-484). Oxford: Oxford University Press.

Silins, H., Zarins, S., \& Mulford, B. (2002). What characteristics and processes define a school as a learning organisation? Is this a useful concept to apply to schools? International Education Journal, 3,
24-32.

Simola, H., Rinne, R., \& Kivirauma, J. (2002). Abdication of the education state or just shifting responsibilities? The appearance of a new system of reason in constructing educational governance and social exclusion/inclusion in Finland. Scandinavian Journal of Educational Research, 46, 247-264. doi:10.1080/0031383022000005661

Skiba, R., Simmons, A., Ritter, S., Kohler, K., Henderson, M., \& Wu, T. (2006). The context of minority disproportionality: Practitioner perspectives on special education referral. Teachers College Record, 108, 1424-1459.

Skrtic, T. M. (1995). Special education and student disability as organization and change. In T. Skrtic (Ed.), Disability and democracy: Reconstructing (special) education for postmodernity (pp. 5-22). New York: Teachers College Press.

Spillane, J. P., Reiser, B. J., \& Reimer, T. (2002). Policy implementation and cognition: Reframing and refocusing implementation research. Review of Educational Research, 72, 387-431. doi:10.3102/00346543072003387

Troia, G. A., Shankland, R. K., \& Wolbers, K. A. (in press). Motivation research in writing: Theoretical and empirical considerations.

US Department of Education (DOE). (2002). No Child Left Behind Act of 2001. Washington DC: Author. Retrieved October 2, 2006, from the U. S. Department of Education Website http://www.ed.gov

US Department of Education. (2003). Meeting the highly qualified teachers challenge: The secretary's second annual report on teacher quality. Washington, D.C.

US General Accounting Office (GAO). (2004). Special education: Additional assistance and better coordination needed among education offices to help states meet the NCLBA teacher requirements (Report to the Ranking Minority Member, Committee on Health, Education, Labor, and Pensions, U.S. Senate No. GAO-04-659).

US General Accounting Office. (2003). Comparison of achievement results for students attending privately managed and traditional schools in six cities. Report (GAO-04-62) to the Chairman, Committee on Education and the Workforce, House of Representatives.

Weatherly, R., \& Lipsky, M. (1977). Street-level bureaucrats and institutional innovation: Implementing special education reform. Harvard Educational Review, 47, 171-197.

Wood, G. (2004). A view from the field: NCLB's effects on classrooms and schools. In D. Meier, \& G. Wood (Eds.), How the No Child Left Behind Act is damaging our children and our schools: Many children left behind (pp. 33-50). Boston: Beacon Press. 